\title{
SCREEN PRINTED METALLIZATION OF SILICON SOLAR CELLS
}

\author{
L. FRISSON, Ph. LAUWERS, $\dagger$ R. MERTENS, $\$$ R. VAN OVERSTRAETEN and R. GOVAERTS \\ Katholieke Universiteit Leuven, Departement Elektrotechniek, Afdeling E.S.A.T. \\ Kardinaal Mercierlaan 94, 3030 Heverlee, Belgium
}

(Received September 7, 1979)

\begin{abstract}
This paper presents a screen printing process for the metallization of silicon solar cells. The physics and construction of a classical solar cell are reviewed. The results obtained with a screen printing process are comparable with other, more ex pensive technologies. This technology does not introduce an additional contact resistance on silicon. The process optimization and the influence of different parameters are discussed.
\end{abstract}

\section{INTRODUCTION}

The research and development of solar cells has grown considerably in the past few years, spurred on mainly by the potential use of these cells for large scale terrestrial solar energy applications. The United States Department of Energy predicts a cost reductiòn from $\$ 20.00$ per peak Watt in 1976 to $\$ 0.50$ per peak Watt in 1986 (Figure 1). With this cost projection they predict an annual market of $10 \mathrm{GW}$ to $20 \mathrm{GW}$ per year in 1990.

The silicon solar cell is one of the simpler semiconductor device structures and consists of a single $\mathrm{n}-\mathrm{p}$ junction (Figure 2).

If solar radiation falls on the upper side of the solar cell the light will be absorbed by the material and will generate electron-hole pairs. The internal electric field at the $n-p$ junction is of such a polarity that the minority carriers are driven towards the junction. This process builds up excess charge, causing a potential difference of about 500 to $600 \mathrm{mV}$ between the n-type and p-type silicon. When the cell is connected to a load a current will flow. To make an electrical contact on the upper side of the solar cell a finger pattern of conductor material is deposited. Connection to the bottom side is made by a metal film covering the whole surface. All the contacts have to be ohmic.

Figure 3 gives the I-V characteristic in darkness and under illumination. $\mathrm{V}_{\mathrm{Oc}}$ is the open circuit voltage, $I_{s c}$ is the short circuit current and $P_{\max }$ is the maximum power point. The fill factor of the solar

$\dagger$ Ph. Lauwers is supported by the I.W.O.N.L.

$\ddagger R$. Mertens is supported by the N.F.W.O. cell is:

$$
\mathrm{FF}=\frac{\mathrm{V}_{\text {max }} \cdot \mathrm{I}_{\text {max }}}{\mathrm{V}_{\mathrm{oc}} \cdot \mathrm{I}_{\mathrm{sc}}}
$$

The equivalent circuit of a solar cell (Figure 4) consists of a diode in parallel with a current source, delivering a current proportional to the incident light level. The parallel resistor represents the leakage while the series resistor represents the series resistance of the solar cell.

\section{FABRICATION}

The fabrication (Figure 5) of a silicon solar cell starts with a Czochralski grown p-silicon wafer as the base material. A phosphorus diffusion generates a ${ }^{+}$layer with a thickness of about $0.4 \mu \mathrm{m}$. A back etch removes the parasitic junction. Then the metallization is deposited on front and back side with either an evaporation or a screen printing technology. An anti-reflective coating $\left(\mathrm{TiO}_{\mathrm{x}}\right)$ is also spun on. The screen printing process is applicable to two process steps of the silicon solar cell fabrication: the junction formation and the metallization. For the junction formation a phosphorus doped paste is screened on the front side and diffusion occurs at a temperature of about $900^{\circ} \mathrm{C}$.

This paper emphasizes the optimization of screened ohmic contacts. The screen printing process for the metallization of silicon solar cells uses thick film technology and lends itself much more to automation than the conventional vacuum 


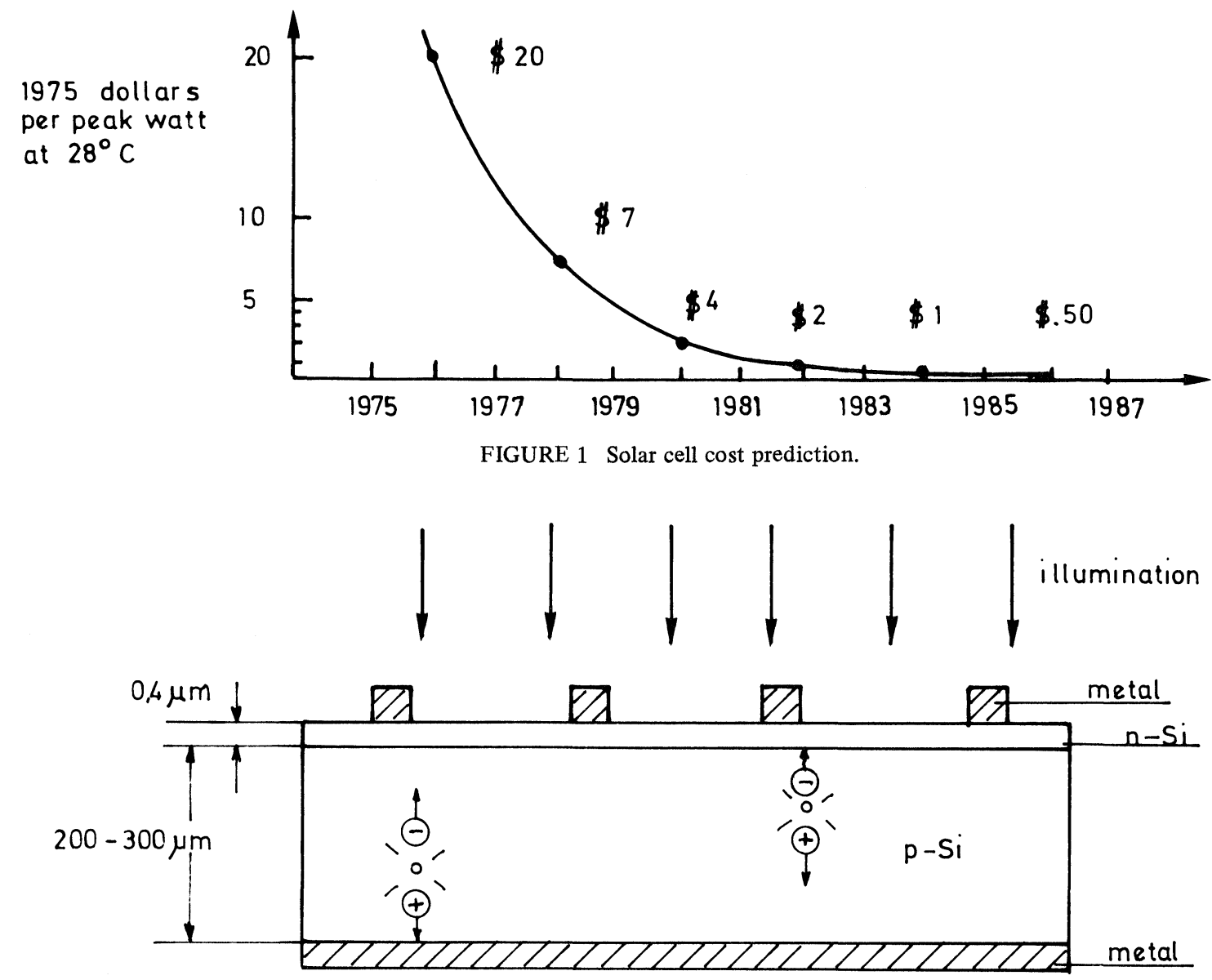

FIGURE 2 Solar cell cross-section.

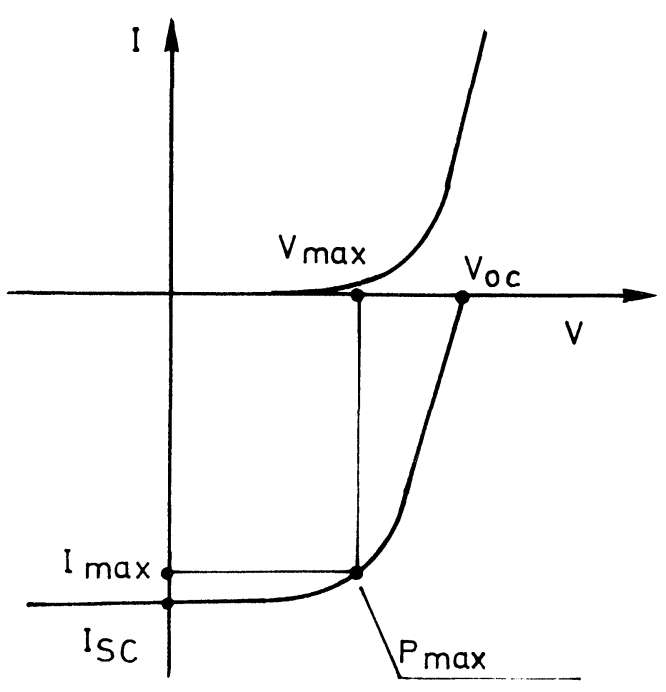

FIGURE 3 I-V characteristic.

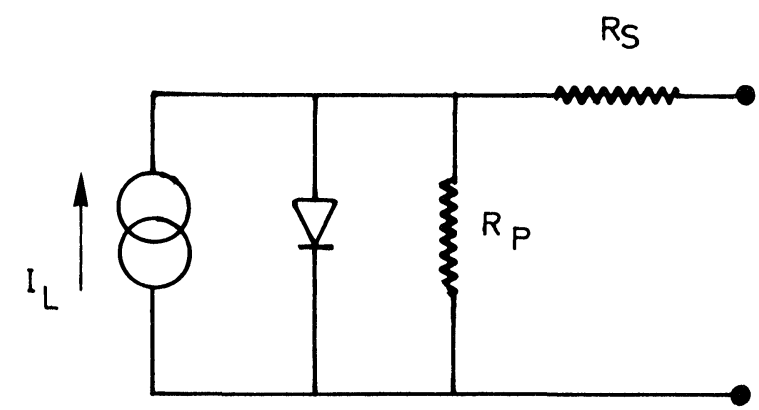

FIGURE 4 Equivalent circuit.

evaporation. The evaporation is a hand operated batch and vacuum process and it has a high facility cost. The screen printing technology avoids all these disadvantages with almost the same final efficiency. It is easy to fully automate, so it gives a cost reduction of the processing of $60 \%$ to $80 \%$. 

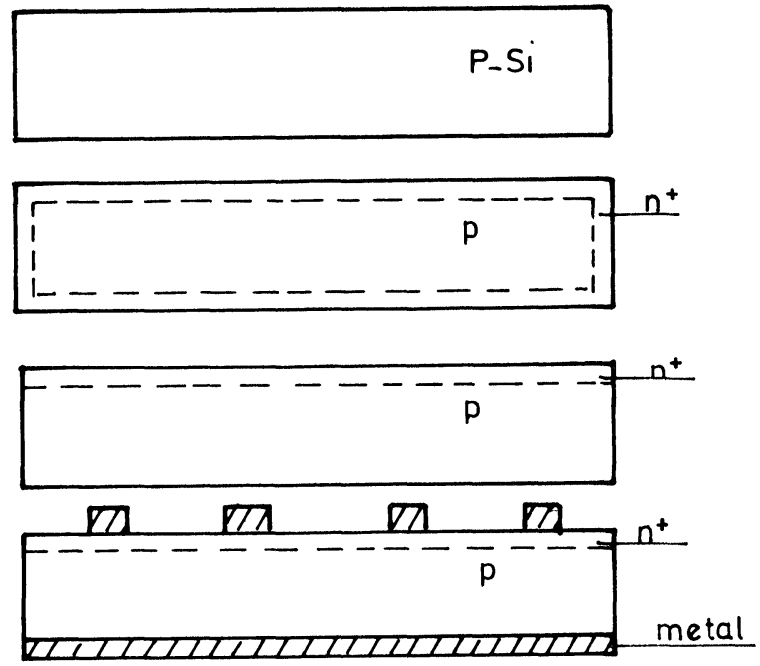

FIGURE 5 Fabrication steps of a silicon solar cell.

\section{PROCESS OPTIMIZATION}

The first great difference with an evaporation technology is that the front metallization pattern is screened on the anti-reflective coating $\left(\mathrm{TiO}_{\mathrm{x}}\right)$ instead of evaporation directly on the silicon. This yields a good electrical contact and at the same time the anti-reflective coating forms a barrier against the diffusion of impurities into the solar cell. A commercially available silver paste (ESL 5964 or similar) to which a few percent of $\mathrm{Ti}$ powder is added, is screen printed on the front side, using a grid contact configuration. To minimize the contact resistance, the paste has to be fired at a temperature of $860^{\circ} \mathrm{C}$. Afterwards an aluminium paste (Engelhard T2497 or similar) is screen printed on the back side to form a $\mathrm{p}^{+}$back surface due to aluminium diffusion; at the same time it produces an ohmic contact. The aluminium paste is air fired at a temperature of $660^{\circ} \mathrm{C}$ to $720^{\circ} \mathrm{C}$. To obtain solderable contacts a

TABLE I

Best results on cells of $1 / 22$ in. wafer.

Cell size: $10 \mathrm{~cm}^{2}$. Metal coverage: $8 \%$. All values at $\mathrm{AMl}$ illumination: $100 \mathrm{~mW} / \mathrm{cm}^{2}$ and temperature of $25^{\circ} \mathrm{C}$.

\begin{tabular}{|c|c|c|c|c|c|}
\hline Process & $\begin{array}{l}\text { Substrate } \\
\text { Resistivity } \\
\Omega \mathrm{cm}\end{array}$ & $\begin{array}{l}\mathbf{J}_{\mathbf{s c}} \\
\mathrm{mA} / \mathrm{cm}^{2}\end{array}$ & $\begin{array}{l}\mathrm{V}_{\mathrm{oc}} \\
\mathrm{mV}\end{array}$ & FF & $\begin{array}{l}\eta_{\%} \text { AM1 } \\
\%\end{array}$ \\
\hline Screen pr. & 10 & 27.5 & 609 & 0.75 & 12.5 \\
\hline Screen pr. & 1 & 27.3 & 608 & 0.76 & 12.6 \\
\hline Evaporation & 1 & 27.9 & 606 & 0.76 & 12.9 \\
\hline
\end{tabular}

$\mathrm{Cu}$-layer is deposited, using an electroplating process, followed by a solder dip. This process yields also a lower sheet resistance of the finger pattern and decreases the series resistance of the solar cell. The results, reported here, are obtained on different sizes of cells. The best results for $1 / 22 \mathrm{in}$. wafers are given in Table I. As can be seen, excellent open circuit voltages and fill factors are obtained, while the short-circuit currents are somewhat lower than for evaporated cells. This is due to the slightly deeper junction necessary to avoid leakage during the firing of the silver paste at this high temperature. Similar results are obtained with 3 in. wafers.

Average values under AMl illumination of $\mathrm{J}_{\mathrm{sc}}$, $\mathrm{V}_{\mathrm{oc}}, \mathrm{FF}$ and efficiency calculated out of different batches of 50 cells are given in Table II.

TABLE II

Average AMl values for $1 / 22$ in. wafers. Substrate resistivity $1 \Omega . c m$. Metal coverage: $8 \%$.

\begin{tabular}{llll}
\hline $\begin{array}{l}\mathrm{J}_{\mathrm{sc}} \\
\mathrm{mA}\end{array}$ & $\begin{array}{l}\mathrm{V}_{\mathrm{Oc}} \\
\mathrm{mV}\end{array}$ & $\mathrm{FF}$ & $\begin{array}{l}\eta_{\mathrm{AM} 1} \\
\%\end{array}$ \\
\hline 27 & 600 & 0.73 & 11.8 \\
\hline
\end{tabular}

\section{INFLUENCE OF DIFFERENT PARAMETERS}

\subsection{Junction Depth}

The variations in solar cell performance with the junction depth has been measured (Table III). From a junction depth of $0.36 \mu \mathrm{m}$ (sheet resistance of diffused layer is $35 \Omega / \square$ ), the fill factor decreases due to an increase in leakage current.

For evaporation technology, where the optimum junction depth is much smaller $( \pm 0.2 \mu \mathrm{m})$, the silver paste used gives an optimum around $0.45 \mu \mathrm{m}$.

TABLE III

Variations of fill factor in function of junction depth. $1 / 22$ in. wafers under AMl illumination. Substrate resistivity $1 \Omega . \mathrm{cm}$. Metal coverage is $8 \%$.

\begin{tabular}{|c|c|c|c|c|c|}
\hline $\begin{array}{l}\text { Junction } \\
\text { depth } \\
\mu \mathrm{m}\end{array}$ & $\begin{array}{l}\rho \\
\Omega / \square\end{array}$ & $\begin{array}{l}\mathrm{V}_{\mathrm{Oc}} \\
\mathrm{mV}\end{array}$ & $\begin{array}{l}\mathrm{J}_{\mathrm{sc}} \\
\mathrm{mA} / \mathrm{cm}^{2}\end{array}$ & FF & $\begin{array}{l}\eta_{\mathrm{AMI}} \\
\%\end{array}$ \\
\hline 0.58 & 15 & 604 & 24.7 & 0.76 & 11.3 \\
\hline 0.45 & 25 & 606 & 27.0 & 0.74 & 12.1 \\
\hline 0.36 & 35 & 598 & 27.5 & 0.71 & 11.7 \\
\hline 0.31 & 45 & 583 & 27.4 & 0.55 & 8.8 \\
\hline
\end{tabular}




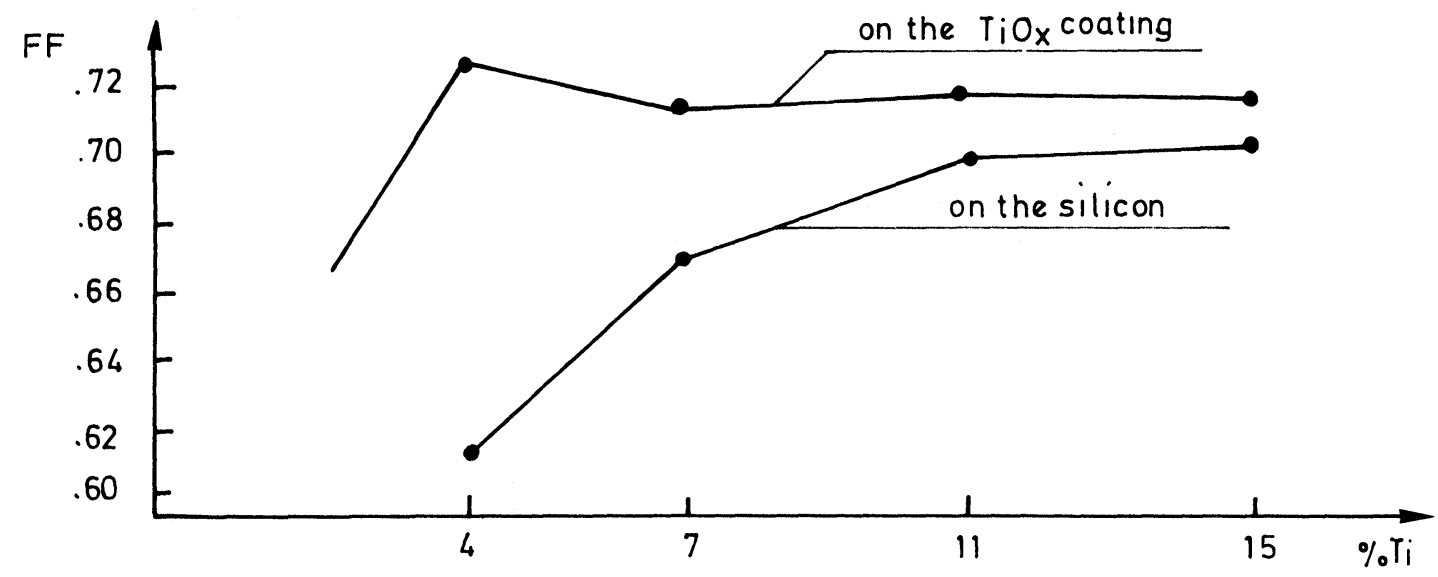

FIGURE 6 Fill factor in function of Ti-concentration.

\subsection{Percentage of Titanium}

Ti improves the quality of the electrical contact of $\mathrm{Ag}$ on $\mathrm{Si}^{2}{ }^{2,4}$ The fill factor as a function of $\mathrm{Ti}$ percentage (Figure 6) has been measured while the screen printing is done on the $\mathrm{TiO}_{\mathrm{x}}$ coating or on the silicon. There is a slight maximum between $4 \%$ and $7 \% \mathrm{Ti}$ for the screen printing on the $\mathrm{TiO}_{\mathrm{x}}$ coating, whereas the maximum is at much higher Ti-concentrations when screen printing is done directly on the silicon. From this we can conclude that the $\mathrm{TiO}_{\mathrm{x}}$ coating has partially the same function as the $\mathrm{Ti}$ in the paste.

\subsection{The Firing Profile}

The optimum firing temperature for the modified silver paste on the front side seems to be around $860^{\circ} \mathrm{C}$ (Figure 7). A slightly lower temperature gives an important increase in series resistance of the solar cell. A slightly higher temperature causes a decrease in output current due to degradation of the lifetime of the minority carriers in the solar cell.

For the Al-paste on the back side an optimum exists for a firing temperature around $660^{\circ} \mathrm{C}$ to $720^{\circ} \mathrm{C}$. The fill factor and with it, the efficiency, improves when the time at peak temperature increases. This is probably due to a diffusion of $\mathrm{Al}$, causing a $\mathrm{p}^{+}$back surface.

\subsection{Screen Printing Parameters}

Snap-off distance and squeegee velocity are not very critical; they have to be chosen to give a good screen printing resolution. Somewhat more critical
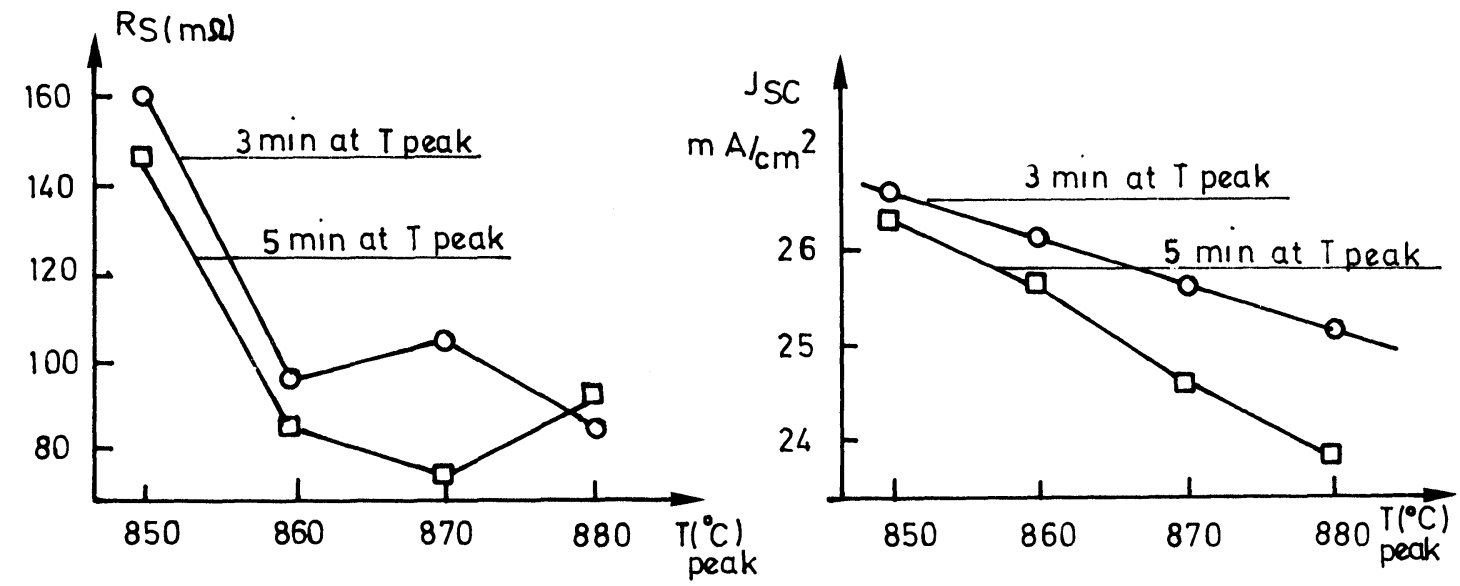

FIGURE 7 Influence of firing temperature on series resistance and the short-circuit current for $1 / 22$ in. wafers. 
is the squeegee pressure. Here one has to take care because a pressure that is too high can easily damage the very shallow junction.

\subsection{Limitation in Line-Width}

Unlike the photolithographical and evaporation technology one has a line-width limited to $150 \mu \mathrm{m}$ while screen printing this particular paste. This has some consequences especially with regard to concentrated sunlight. Operation under highly concentrated sunlight requires very low series resistance corresponding with a very dense metallization grid such that finger widths of $50 \mu \mathrm{m}$ are necessary. However, cells fabricated with a screen printing metallization could still be used for concentration factors up to 30 .

Output parameters of some of our cells are listed in Table IV. It is a $2 \times 6 \mathrm{~cm}$ rectangular cell, optimized for a concentration factor of 15 . The calculated series resistance was $15.4 \mathrm{~m} \Omega$, the measured one was $23.5 \mathrm{~m} \Omega$.

TABLE IV

Output parameters of a $2 \times 6 \mathrm{~cm}^{2}$ cell. Substrate resistivity: $1 \Omega . \mathrm{cm}$. Metal coverage is $12 \%$

\begin{tabular}{lclll}
\hline & $\begin{array}{l}\mathrm{J}_{\mathrm{Sc}} \\
\mathrm{mA} / \mathrm{cm}^{2}\end{array}$ & $\begin{array}{l}\mathrm{V}_{\mathrm{Oc}} \\
\mathrm{mV}\end{array}$ & $\mathrm{FF}$ & $\begin{array}{l}\eta_{\text {AMl }} \\
\%\end{array}$ \\
\hline 1 sun & 25 & 595 & 0.715 & 10.6 \\
4 suns & 100 & 631 & 0.755 & 11.9 \\
\hline
\end{tabular}

\section{CONCLUSIONS}

1) A vacuum free process, using screen printing has been described. It gives an important processing cost reduction with almost the same efficiency.

2) Screen printing of solar cells can be controlled in such a way that it does not introduce any significant contact resistance.

3) Screen printed solar cells can be optimized to be used at concentrations as high as 30 .

\section{ACKNOWLEDGEMENTS}

The research activities presented in this contribution have been partly supported by the Science Policy Programs of the Belgian Government, the Institute for Scientific Research in Industry and Agriculture (IWONL) and the National Foundation for Scientific Research (NFWO).

\section{REFERENCES}

1. E. L. Ralph, "Recent advancements in low-cost solar cell processing", Eleventh IEEE Photovoltaic Specialists Conf. 1975 , p. 315.

2. A. D. Haigh, "Fired through printed contacts on anti-reflection coated silicon terrestrial solar cells", Twelfth IEEE Photovoltaic Specialists Conf. 1976, p. 360.

3. M. B. Field, and L. R. Scudder, "Application of thick-film technology to solar cell fabrication", Twelfth IEEE Photovoltaic Specialists Conf. 1976, p. 303.

4. L. Frisson, et al., "Screen printed contacts on silicon solar cells with low series resistance", Thirteenth IEEE Photovoltaic Specialists Conf. 1978, p. 590. 

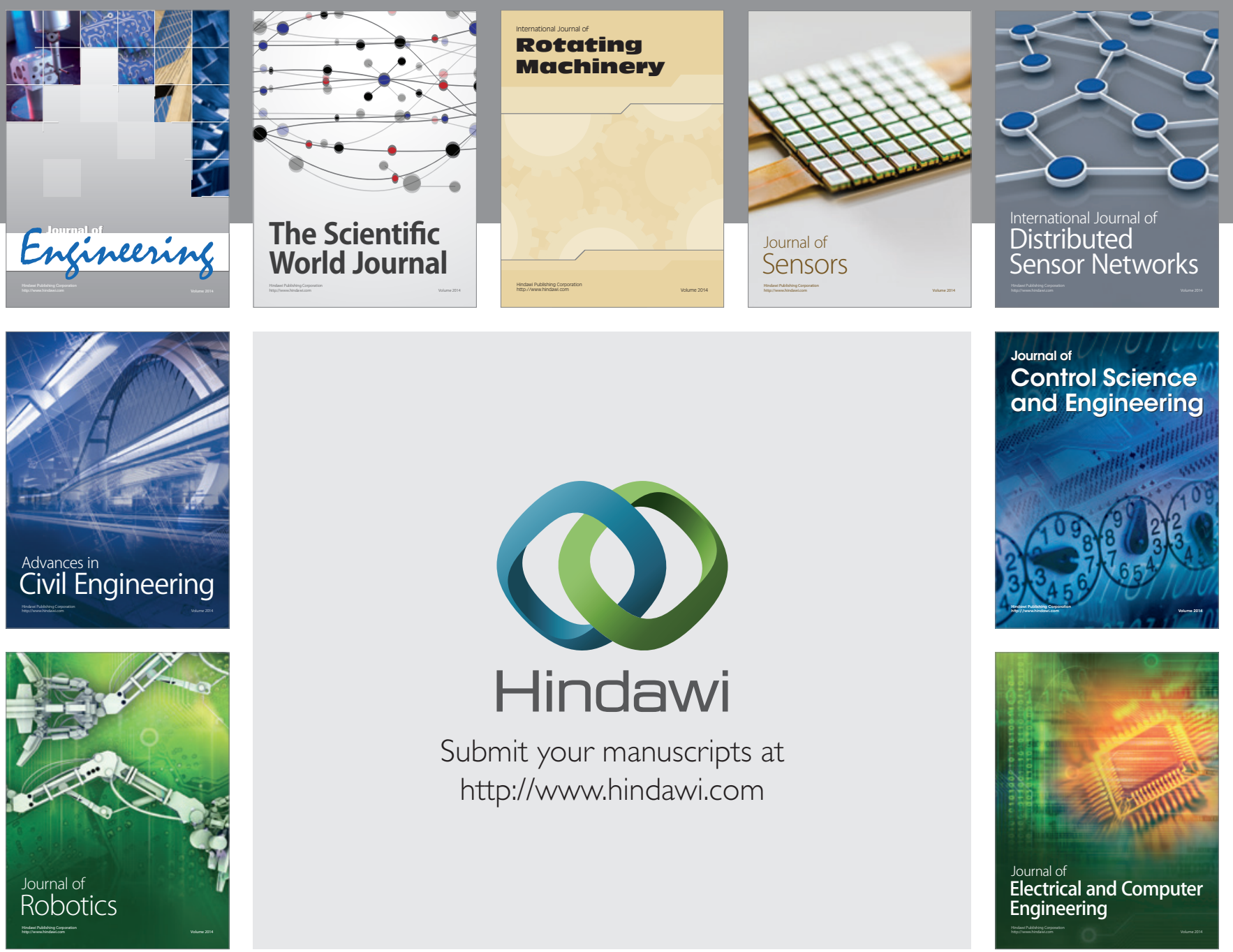

Submit your manuscripts at

http://www.hindawi.com
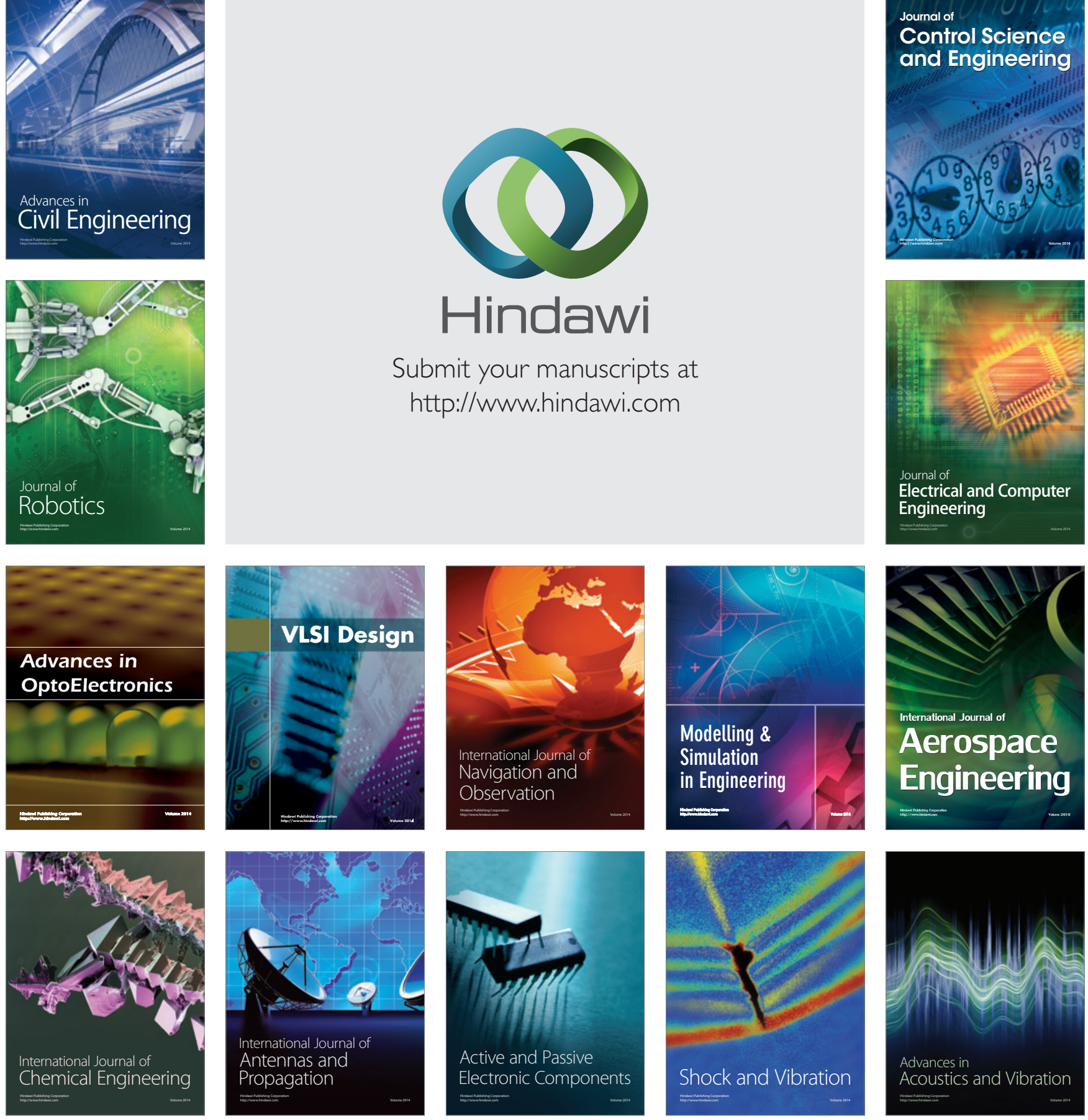